\title{
Australia and India in the Modi era: An unequal strategic partnership?
}

\author{
Ian Hall ${ }^{1}$
}

Accepted: 31 December 2020 / Published online: 2 February 2021

(c) The Author(s), under exclusive licence to Springer Nature Limited part of Springer Nature 2021

\begin{abstract}
Narendra Modi's visit to Australia in November 2014 was the first for an Indian Prime Minister in almost three decades and promised much. Modi declared that Australia was no longer on the 'periphery' of New Delhi's 'vision', 'but at the centre of our thoughts'. He pledged to work with Canberra at the G20 and regional multilateral forums, deepen the bilateral security partnership, and conclude a free trade deal. These promises were only partly realised. Progress was made in defence and security cooperation, within and outside the Quad, but a free trade deal proved too hard. Canberra struggled to maintain momentum in improving ties because of leadership challenges in Australian government and New Delhi's preference for protectionism. This article examines these dynamics, looking back at the drivers of the strategic partnership, as well as at the challenges encountered in the Modi era.
\end{abstract}

Keywords Australia $\cdot$ India $\cdot$ Strategic partnership $\cdot$ Narendra Modi $\cdot$ Indo-Pacific $\cdot$ Regional security

\section{Introduction}

Mid-January 2020 was meant to see a celebration of Australia-India ties, including a keynote address from Australian Prime Minister Scott Morrison at the Raisina Dialogue in New Delhi and a summit with his Indian counterpart, Narendra Modi. ${ }^{1}$ It was not to be. Severe bushfires in south eastern Australia required Morrison to postpone his visit. Instead, Foreign Minister Marise Payne travelled to India with a pared back delegation and a video message from Morrison. Then, the COVID-19

\footnotetext{
1 The Raisina Dialogue is run by the Observer Research Foundation with support from the Government of India.

Ian Hall

i.hall@griffith.edu.au

1 Griffith Asia Institute, Griffith University, 170 Kessels Road, Nathan, QLD 4111, Australia
} 
pandemic intervened. ${ }^{2}$ After some negotiation, the two prime ministers made do with an online 'virtual summit', held on 4 June 2020.

Had Morrison travelled to New Delhi, his visit would have been the sixth by an Australian prime minister to India in just 15 years. ${ }^{3}$ These frequent trips have helped construct a robust strategic partnership between the two countries, despite only one visit to Australia by an Indian leader: Modi in November 2014. So too have multiple ministerial delegations and strategic dialogues between bureaucrats, military officers, and analysts. As a result, the two states now have robust ties, especially in the areas of defence and security, underpinned by far better understandings of each other's perceptions of challenges they face in the Indo-Pacific. Increased flows of students and skilled migrants mean that people of Indian origin now form the third largest group of Australian residents born overseas (Australian Bureau of Statistics 2018). And although bilateral trade and investment remain sluggish and talks to conclude a free trade deal-the proposed Comprehensive Economic Cooperation Agreement (CECA) - have not yet borne fruit, overall the bilateral relationship is far stronger now than it was even a decade ago.

Yet it must be observed that the effort put into building this partnership has been unequal. For the most part, Canberra has made the running (Grare 2017: 118; cf. Medcalf 2011: 206). The election of the Modi's Bharatiya Janata Party-led (BJP) government in May 2014 did raise hopes that New Delhi might invest more in the partnership more energetically than earlier Indian administrations. They were boosted by the Indian prime minister's visit to Australia later that year and his declaration that Australia was no longer at the 'periphery of our vision, but at the centre of our thought' (quoted in Hall 2019a). Whether these hopes were realised, however, remains moot. Since 2014, further progress has been made on the defence and security side of the relationship. But despite Modi's promise to bring trade talks to a rapid and positive conclusion, the CECA was not agreed during his first term in office, and Canberra was also disappointed when New Delhi walked away from the negotiations for the Regional Comprehensive Economic Partnership (RCEP) in late 2019.

With these issues in mind, this article explores why progress in advancing the Australia-India strategic partnership was slower and patchier than expected after the election of the Modi government. To do that, it briefly explores bilateral relations prior to the mid-2000s. It argues that various factors played a part in pushing Canberra to forge closer ties after that point, including the rapprochement between the USA and India, the perception of greater economic opportunities in a fast-growing India, and the emergence of shared concerns about China's power and intentions. It observes the role of ideology in shaping some Australian views of Modi, especially during Tony Abbott's prime ministership, and generating over-optimism about what

\footnotetext{
${ }^{2}$ Due to the Covid-19 outbreak, arranging another trip proved impossible, and so a 'virtual summit' involving Morrison and his Indian counterpart was held.

3 These include visits by John Howard (2006), Kevin Rudd (2009), Julia Gillard (2012), Tony Abbott (2014) and Malcolm Turnbull (2017). To put this in context, between 2006 and 2020, Australian prime ministers visited China, the country's biggest trading partner, only four times (Kevin Rudd, 2008; Julia Gillard, 2013; Tony Abbott, 2014; Malcolm Turnbull, 2016).
} 
the Indian leader might deliver both domestically and for bilateral relations. And it argues that four issues made advancing the strategic partnership harder than anticipated: first, variable political commitment in both capitals, exacerbated by leadership changes in Canberra; second, India's intensified commitment to economic protectionism under the Modi government; third, the instability of the wider environment, especially after Donald J. Trump's election in November 2016; and fourth, persistent misperceptions of the other's positions.

\section{Indifference and re-engagement}

Bound together by British Empire for a century and a half, Australia and India drifted apart after the latter gained independence in 1947. The Commonwealth, New Delhi's need for aid, and the practicalities of travel—which for a while required Australian prime ministers stop in the subcontinent on the way to and from Europe-kept dialogue going during the 1950s and 1960s (Gurry 1992). But bilateral trade declined and divisions emerged over issues like racial discrimination. Cold War exigencies-especially Australia's support for the United States' intervention in Vietnam and, after 1971, India's quasi-alignment with the Sovietspushed the two further apart. Periodic attempts at re-engagement did not yield much beyond an invitation to Malcolm Fraser to be the guest of honour at the Republic Day parade in 1979. The following decade did see a modest increase in trade, with Australia exports more than doubling in value to A \$555 m between 1982-1983 and 1988-1989 (Hall 2014: 132). ${ }^{4}$ Canberra's priorities mostly lay elsewhere, however, as it explored economic opportunities in East Asia, and New Delhi remained largely disinterested in Australia (Mayer and Jain 2010: 144-145).

In the 1990s, efforts were made to overcome this 'mutual indifference' (Grare 2017: 115). At the start of the decade, a landmark Australian Senate report called for the formation of an Australia-India Council (AIC) to promote business links, a cross-department effort to identify strategies to improve ties, and investment in traditional and public diplomacy in India (Australian Senate 1990). A National Centre for South Asian Studies was launched, and a major government study on India's economy and bilateral ties published (DFAT 1994). A series of significant scholarly works on the bilateral relationship also appeared (Gordon 1993, 1995; Gordon and Henningham 1995; Gurry 1996; Vicziany 1993). In parallel, the partial deregulation of the India's economy boosted bilateral trade, which almost doubled in value between 1989-1990 and 1994-1995, from A\$868 m to A \$1.5bn (Hall 2014: 135).

This progress was halted by India's nuclear tests in May 1998 and by Canberra's visceral response. During the 1980s and1990s, Australia was a prominent defender of the nuclear non-proliferation regime. The nuclear tests were therefore not well received - indeed, the reaction from Canberra was 'unrestrainedly vituperative' (Broinowski 2000: 141). Foreign Minister Alexander Downer denounced the tests as 'outrageous acts' (Minister for Foreign Affairs 1998) and Prime Minister

\footnotetext{
4 A trade facilitation agreement had been signed in 1976 (Weigold 2011: 39).
} 
John Howard referred to India's soon-to-be constructed nuclear weapons as a 'grotesque status symbol' (Broinowski 2000: 145). Australia's High Commissioner was recalled for consultations, the Defence Attaché withdrawn, and defence cooperation suspended. Canberra also lobbied for a condemnation of the tests at the ASEAN Regional Forum (ARF) meeting in July 1998 (Kaul 2000: 366). In turn, New Delhi denounced these actions as unreasonable, disrespectful, and hypocritical, noting that Australia benefits from American extended nuclear deterrence (Borah 2008: 177; cf. Bonnor 2001: 6; Gopal and Ahlawat 2015: 212).

Two years passed before the relationship was patched up. In March 2000, Downer went to New Delhi and secured agreement for a prime ministerial visit in July. Once in India, Howard observed that Canberra still did not approve of India's deterrent, but did not want it to 'contaminate' bilateral ties (Suryanarayana 2000). A foreign minister-level Framework Dialogue followed in June 2001, with Jaswant Singh travelling to Adelaide, and then talks between officials on a series of security and economic issues (DFAT 2001). Catalysed by the 9/11 attacks and the threat from militant Islamism, these conversations led to an intelligence sharing arrangement (DFAT 2003; cf. Panda and Baruah 2010: 210-211). Little more was done, however, until after the unveiling of the US-India nuclear deal in July 2005, which paved the way for New Delhi to trade in civilian nuclear technology. ${ }^{5}$ That deal-and a 10-year Defense Framework Agreement-signalled Washington's determination to make India a strategic partner. ${ }^{6}$ And it opened the door to US allies, including Australia and Japan, to begin to construct closer ties of their own. ${ }^{7}$

In Canberra's case, this process was eased by India's impressive economic performance in the early 2000s (Gurry 2012). When Howard went to New Delhi in 2006, a large delegation of business and university leaders, eyeing opportunities, was keen to go too. The main product of the visit was, however, an MoU on defence cooperation that detailed dialogues, exchanges of military officers, joint naval exercises, and ship visits. This reflected the emerging view in the Canberra defence establishment that as 'India's strategic stature grows its capacity to contribute positively to...[Australia's] strategic interests increases' (Department of Defence 2006: 4). In pursuit of that aim, in May 2007 the Howard government took the controversial decision to involve Australia in the Quadrilateral Security Dialogue (QSD or 'Quad'), along with India, Japan and the USA (Gyngell 2017: 293-294). ${ }^{8}$ Convened on the sidelines of an Association for South East Asian Nations (ASEAN) summit in Manila, in the Philippines, the Quad brought together officials for an 'exploratory' discussion on issues of common concern in the region (Madan 2017).

\footnotetext{
5 For a useful analysis for the deal, see Mistry (2014).

6 This process grew out of the talks between Strobe Talbott and Jaswant Singh that followed India's nuclear tests, and the 2004 Next Steps in Strategic Partnership agreement. See Tellis (2005).

7 On the India-Japan strategic partnership, see Basrur and Narayanan Kutty (2018).

${ }^{8}$ On regional minilateralism, see Tow (2019), and on the role of minilaterals in regional security governance, see Envall and Hall (2016).
} 


\section{Disagreements, asymmetries and misperceptions}

In the late 2000s and early 2010s, the emerging Australia-India strategic partnership came under strain. More progress was made in building stronger defence and security ties. But Australia's longstanding ban on selling uranium to India emerged as a significant irritant. A succession of short-lived governments in Australia-which had four prime ministers from two different parties between 2007 and 2015-also undermined policy continuity, even in defence and foreign affairs. And in New Delhi, Manmohan Singh's Congress Party led government sank into torpor and corruption after its re-election in May 2009, with knock-on effects on its diplomacy.

Australia's uranium ban had been imposed because India had refused to sign the 1968 Non-Proliferation Treaty (NPT). ${ }^{9}$ While legally defensible, the ban was questioned by New Delhi, not least because Australian uranium had been sold to states with problematic proliferation records, including China (Shekhar 2010: 404). In 2005 , it was further undermined by the US-India nuclear deal, which opened up trade with India in civilian nuclear technology (Kelly 2006: 66). Some-including Howard himself-argued that deal meant the Australian ban was no longer tenable. Others-especially in DFAT, which was deeply invested in the cause of non-proliferation-disagree. Meanwhile, New Delhi pressed hard for the ban to be removed. In August 2007, Howard decided to break the impasse, and advised Manmohan Singh during a visit to New Delhi that his government would move to lift the ban (Australian Associated Press 2007). The matter was still unsettled, however, when Howard lost the general election four months later.

Howard's replacement, the mercurial Mandarin-speaking former diplomat Kevin Rudd, leader of the Australian Labor Party (ALP), had earlier made it clear that he favoured maintaining the ban. Perceived by some as too close to China (Medcalf 2008) and largely disinterested in India (Lee 2009), Rudd followed the DFAT line that India must sign the NPT before it could be lifted (Mayer and Jain 2010: 140). To make matters worse, Rudd then pulled out of the Quad. New Delhi also had doubts about the minilateral, but the way in which the Rudd government made the announcement-at a press conference at which the Chinese foreign minister Yang Jiechi was present-irritated New Delhi (Madan 2017). The episode cast a long shadow over the partnership, and prompted India to shut Australia out of a significant naval exercise-dubbed MALABAR - that it convened every year with the USA and others in the Indian Ocean (Singh 2019).

These anxieties did not dissipate, but they were soon overtaken by others. Beijing's new assertiveness after the Global Financial Crisis (GFC) of 2008-2009 unsettled both Canberra and New Delhi, stimulating another push for closer security ties and for more coordinated action. ${ }^{10}$ Belatedly, Rudd moved to repair relations with India. In February 2009, he sent Peter Varghese, a highly respected diplomat

\footnotetext{
9 On the ban and associated political debates, see Clarke (2011), Roy (2011) and Thakur (2013).

10 On China's assertiveness, see Friedberg (2014). On multilateral initiatives, including the Indian Ocean Naval Symposium and the Indian Ocean Region-Association for Regional Cooperation (now the Indian Ocean Regional Association), see Grare (2017: 132).
} 
then the head of the Office of National Assessments (ONA), as the new High Commissioner to India. ${ }^{11}$ Two months later, his government published a Defence White Paper signalling a desire to strengthen security ties with New Delhi (Department of Defence 2009). In the Indian capital in November 2009, Rudd and Manmohan Singh then signed a Joint Declaration on Security Cooperation and upgraded the bilateral relationship to a 'strategic partnership' (Brewster 2010; cf. Panda and Baruah 2010).

More progress followed Rudd's replacement as Australian Prime Minister by Julia Gillard. In May 2011, negotiations commenced for a bilateral Comprehensive Economic Cooperation Agreement (CECA). Six months later, Gillard secured her party's support to lift the uranium ban and start talks on a civil nuclear deal. In New Delhi in October 2012, Gillard and Singh also agreed that annual prime ministerial meetings should be held (Department of Prime Minister and Cabinet 2012). In the same month, Gillard's government also published the so-called Asian Century White Paper-a plan for Australia's engagement with what Canberra was now called the 'Indo-Pacific' - which mentioned India more than a hundred times in multiple contexts (DFAT 2012). Another Defence White Paper soon followed, which also employed the India-inclusive Indo-Pacific terminology and welcomed India's emergence as a 'global power' (Department of Defence 2013).

By this time, however, it was clear that India's economic growth was faltering, thanks partly to the impact of the GFC. Between 2004 and 2008, growth had averaged 8.8\% (Mehra 2019: 21). But after a short-lived bump following the financial crisis, it did not again reach that level. The fiscal stimulus New Delhi employed to manage the economic downturn built up debt, failed to improve productivity, and increased prices, especially for basic foodstuffs. Between 2011 and 2014, growth averaged only $6.5 \%$, at or below the rate of inflation (Soz 2019: 145). Meanwhile, the government became ever more deeply mired in a succession of corruption scandals. And in parallel, it appeared increasingly sceptical of closer ties with the USA, with knock-on effects for ties with allies like Australia (Burns 2014).

These developments caused jitters in Canberra about India's capacity to emerge as both a regional economic powerhouse and security provider (Grare 2017: 132-133; cf. Gordon 2014). Worries also emerged about New Delhi's commitment to the bilateral partnership. During the ten years that the Singh government was in office, from May 2004 to May 2014, India's External Affairs ministers visited Australia three times (Pranab Mukherjee in 2008; S. M. Krishna in 2009 and 2011), and the prime minister not at all. By contrast, during the same period, there were seven trips by foreign ministers to New Delhi and three by Australian prime ministersten in total. ${ }^{12}$ This imbalance generated doubts about whether India saw Australia as a partner worthy of sustained attention (Medcalf 2011: 206).

\footnotetext{
${ }^{11}$ ONA-renamed the Office of National Intelligence (ONI) in 2018-is Australia's peak intelligence agency. Varghese returned from New Delhi to serve as head of DFAT.

12 Australian Defence Minister Stephen Smith also went to India in December 2011 and A. K. Antony to Australia in June 2013.
} 


\section{The Modi moment}

The rise of Narendra Modi and the resounding victory won by his BJP-led coalition in the May 2014 election raised hopes in Canberra that the bilateral relationship might be re-energised and progress made on trade and investment. Neither Modi nor the BJP said very much about foreign policy during the long election campaign (Hall 2019b: 3-4). But Australian politicians and diplomats were cautiously optimistic that Modi might be able to bring to New Delhi the same technocratic, business-friendly approach to governance he had adopted as Gujarat's Chief Minister and a more liberal foreign economic policy (Medcalf and Rajendram 2014). For that reason, Australia's High Commissioner Patrick Suckling became one of the first Western ambassadors to meet Modi in August 2013 and to invite him to visit Australia, a gesture that was apparently appreciated (Hindustan Times 2013). Others in Canberra-especially on the right wing of the Liberal Party, including Tony Abbott, who became Prime Minister in September 2013were even more enthusiastic, perceiving Modi as an ideological ally (Chacko and Davis 2017).

Keen to make a good impression, Abbott quickly reached out to the new Indian prime minister, first with a phone call, and then with a congratulatory tweet (Modi 2014). Abbott told Modi he looked forward to welcoming him to Australia for the G-20 meeting and a state visit. In September, Abbott then became one of the first leaders from outside South Asia to visit Modi in New Delhi. He took with him a bilateral civilian nuclear agreement, a delegation of business and university leaders, and deals on cooperation in sport, water management, and vocational training. The two prime ministers also announced that regular bilateral joint naval exercises - dubbed AUSINDEX - would begin in 2015, and that both governments would revitalise the Australia-India CEO Forum. Abbott reiterated Australia's support for a permanent seat for India on the United Nations Security Council and membership of the Asia Pacific Economic Cooperation (APEC) forum (DFAT 2014a).

Abbott's enthusiasm carried over to Modi's trip to Australia in November-the first by an Indian prime minister since Rajiv Gandhi in 1986. In Canberra, Modi was warmly received at a joint sitting of parliament, and warmer still at a series of events for members of the Indian diaspora held in Brisbane, Melbourne and Sydney (Wade 2014). The Indian Prime Minister reciprocated by calling Australia a 'vital partner' and observing that it had a big role to play in improving education and training, housing, electricity, agriculture, healthcare, finance and infrastructure in India (MEA 2014). He pledged to accelerate negotiations for the CECA, with the aim of finalising the deal by the end of 2015 (DFAT 2014b; cf. Brewster 2017: 29). Abbott and Modi also unveiled a new Framework for Security Cooperation (Brewster 2015).

Modi's visit was followed by a marked intensification of security cooperation and a convergence in the language used to discuss regional challenges. In January 2015, New Delhi began to include the phrase 'rules-based order' —or variations on it-in a series of statements on the 'Indo-Pacific' - terms long favoured 
by Canberra. 'Rules-based order' first appeared in the 'India-US Delhi Declaration of Friendship' released to mark US President Barack H. Obama's attendance at the Republic Day celebrations in New Delhi (MEA 2015), and thereafter in multiple statements, including Modi's significant speech at the Shangri-La Dialogue in June 2018 (MEA 2018). ${ }^{13}$ This linguistic alignment-intended to signal to third parties, and especially China, that Australia and India, along with Japan and the USA, were indeed 'like-minded' on regional security challenges and the best ways of managing them. In June 2015, the heads of the Australian, Indian, and Japanese foreign ministries met in New Delhi for the first annual trilateral dialogue (Lang 2015). Three months later, the first AUSINDEX took place, followed by a bilateral maritime security dialogue and a visit by Australian Defence Minister Kevin Andrews to New Delhi (Department of Defence 2015).

\section{Losing and gaining momentum}

September 2015 saw two other consequential developments. The first was the toppling of Tony Abbott by Malcolm Turnbull, one of his rivals within the Liberal Party. A political centrist sceptical of his predecessor's views, Turnbull shared Abbott's concerns about China's growing power and ambition, but not his enthusiasm for Modi or India. ${ }^{14}$ As a wealthy businessperson and banker, he was critical of New Delhi's protectionist preferences and perceived that doing business in India was unnecessarily difficult (Turnbull 2020: 488). The second development-the suspension of the CECA talks at around the same time Turnbull took over-likely confirmed those views. Canberra had hoped a deal might be concluded, especially after Modi's earlier endorsement. During the fifth round of negotiations, however, it was clear that agreement could not be reached (Turnbull 2020: 489; cf. Brewster 2017: 36-38).

The combination of Turnbull's relative disinterest and the failure of the CECA negotiations overshadowed bilateral ties for more than eighteen months. So too did the failure of the Modi government to markedly boost the economy and implement a more liberal economic agenda. At the 2014 election, the BJP had promised both a much higher rate of growth and more business-friendly policies, with Modi urging Indians to adopt a more positive view of the opportunities presented by globalisation. During a series of overseas visits in his first year in office, Modi had wooed foreign investors to inject funds into manufacturing under the banner of 'Make in India' (Soz 2019: 95-99). He had pledged both deregulation and major investments in infrastructure, including work to address the woeful condition of road, rail and maritime connectivity in South Asia and the Indian Ocean region. All of this was intended to turn India into a global manufacturing powerhouse, as well as major

\footnotetext{
13 On India's use of the language of the 'rules-based order' under Modi, see Hall (2020a).

14 Turnbull's lengthy, 660 page, memoirs devote barely two pages on the Australia-India relationship, all focused on a visit to New Delhi in April 2017. By contrast, China is accorded a whole chapter (Turnbull 2020: 488-490; 408-435).
} 
centre for global services, lifting employment, skill levels, wages, intellectual property, and growth. It also raised hopes that under Modi, India would close a series of free trade deals, some stalled for several years under the previous government, including the CECA (Palit 2017).

These hopes had faded by the middle of Modi's first 5 years in office. As a result, foreign direct investment spiked in 2014-2016, then tailed off (Soz 2019: 180). Growth trundled along at a rate not much above that achieved in the early 2010s, hitting a high of $8 \%$ in 2015, but declining to 7\% in 2016 and $6.6 \%$ in 2017 (Soz 2019: 145). Negotiations for free trade agreements, with Canada and the European Union, as well as Australia, ground to a halt. Together, these developments dented confidence in Canberra about the economic relationship, confirming the views of India sceptics like Turnbull (Bisley 2017). The Australian Prime Minister continued to use warm language about India in major speeches on foreign policy, but he was far from effusive (Turnbull 2016; cf. Chubb 2017: 278-279). Defence and security cooperation carried on, reflecting the assessment of the 2016 Australian White Paper that the two countries shared 'key interests in regional stability and order' (Hall 2016: 184). But no new India-focused initiatives emerged between Turnbull's takeover in September 2015 and his five-day visit to India in April 2017. And even when the Australian Prime Minister went to New Delhi, the announcements made concerned security issues, not trade and investment. ${ }^{15}$

This loss of enthusiasm and momentum might have persisted had it not been for developments beyond Australia and India. A worsening of the global situation ensured that-like the Rudd government in 2008 and 2009-the Turnbull administration was forced to re-evaluate its approach to India, and the Modi government its approach to Australia. Two developments were particularly problematic. The first was Donald J. Trump's election as President of the United States of America in November 2016, which shocked both capitals. Trump's persistent questioning of trade balances and alliance commitments before and after his win were a major concern (Rajagopalan 2017; Tow 2017). His withdrawal from the Trans-Pacific Partnership struck a blow to Australia's efforts to diversify its economic links beyond China (Kehoe 2016). In parallel, his threats to restrict visas for skilled workers and to impose punitive tariffs on certain goods and services coming into the USA from India, among other countries, rattled New Delhi (Ladwig and Mukherjee 2017). In both capitals, and others, like Tokyo, politicians and officials realised that they needed to act to fill some of the void left by the absence of US leadership in the region and the diplomatic turbulence generated by Trump.

The second development was an intensification of China's assertiveness across the Indo-Pacific, which began in the late 2000s and broadened after Xi Jinping's rise to power in late 2012. In 2017, Beijing presented Australia and India with a series of difficult challenges, exacerbating pre-existing tensions in their bilateral relations with China. A major one was the first Belt and Road Forum (BRF), held in Beijing in early May, hosted by Xi. Both Australia and India had hedged on the BRI

15 These included an agreement on cooperation on counter terrorism and organised crime (DFAT 2017a, b). 
since its launch in the second half of 2013, refusing to endorse it but equally holding back from criticising it. Now, with Beijing issuing invitations to heads of state and government to attend the BRF, and asking for public pledges of support, they were faced with a choice. Canberra decided on a low-profile approach, sending trade minister Steve Ciobo, who made non-committal remarks. By contrast, New Delhi demurred until the last minute and then took a confrontational line, issuing a vehement critique of the BRI, denouncing its intentions and its likely impact on debtors, the world economy, and the environment (MEA 2017; cf. Hall 2020b). Then, two months later, Indian troops became embroiled into a dangerous standoff with Chinese soldiers at Doklam, in a disputed area of Bhutan, during which Beijing's staterun media made multiple threats of war (Kaura 2020).

These developments, combined with others-such as the mounting evidence of widespread attempts by Chinese interests to influence and interfere in Australian politics highlighted by the case of Senator Sam Dastaryi (Medcalf 2019: 114)—convinced both Canberra and New Delhi that renewed effort had to be made in strengthening their strategic partnership as insurance against an erratic regime in Washington and an assertive one in Beijing. Mindful of these considerations, Turnbull asked Peter Varghese, the former High Commissioner to India, to identify possibilities for greater trade and investment that did not require the CECA (Campbell 2017). Australia also intensified its efforts to ensure India signed up to RCEP, the ASEAN-centric trade agreement then under negotiation (Derewlany 2017). And despite mutual misgivings about the Trump administration, in November 2017, Canberra and New Delhi agreed to reconvene the Quad, again initially in Manila, and to hold further, regular meetings of the minilateral to discuss issues of mutual concern, including maritime security and impact of the BRI on the region (Graham et al. 2018).

At the same time, Australia and India redoubled efforts to strengthen their bilateral defence and security ties. In a Foreign Policy White Paper published in November 2017, Canberra reaffirmed its pledge to seek a 'first order' partnership with India (DFAT 2017a, b: 42). The following year-2018-Australia and India convened no fewer than 38 bilateral security dialogues or joint military exercises, compared to just 11 in 2014 (Bachhawat 2019). These included Indian Air Force participation in the large-scale multilateral air defence exercise run biennially in northern Australia dubbed PITCH BLACK. Towards the end of the year, the focus turned again to the economic side of the relationship. Late November saw the first ever visit by an Indian President to Australia, with Ram Nath Kovind spending three days in Melbourne and Sydney. The occasion was marked by the release of the government's response to Varghese's monumental and minutely detailed India Economic Strategy to 2035 (Varghese 2018). Analysing the economic relationship sector by sector, from tourism to science and innovation, and state by state, the Strategy was adopted as a roadmap for Australia's diplomats, businesses and universities to allow them to navigate India's economy in the absence of a CECA (Jeffrey 2018).

Worryingly for Canberra, all of this effort on the Australian side was not reciprocated. In 2018, New Delhi promised a parallel Australia Economic Strategy, but publication was repeatedly delayed. More troubling, however, was New Delhi's foot-dragging over the RCEP deal, which finally ended with an abrupt withdrawal from negotiations in early November 2019 (PTI 2019). Following the suspension 
of talks for the CECA, Canberra had hoped that RCEP would provide at least some enhanced access for Australian firms into India's market (Wilson 2019). New Delhi's decision to walk away, citing concerns about China and its growing trade deficit with its northern neighbour, was therefore a blow, albeit one that confirmed doubts in Canberra about the Modi government's commitment to liberalisation. And to an extent, it also demonstrated the limits of Australia's diplomatic clout in India. Successive High Commissioners had worked hard to persuade New Delhi of the virtues of freer trade, but apparently to little avail. ${ }^{16}$

\section{A new equilibrium?}

In May 2019, general elections took place in both Australia and India. Unexpectedly, Scott Morrison, who had replaced Turnbull as Prime Minister in August 2018, was returned to government with a slim majority. Modi's win, by contrast, was far more convincing. Both were hailed in both countries as positive for the bilateral relationship. Increasingly wary of China, Morrison and his conservative backers within the Liberal Party were perceived as more enthusiastic about stronger ties with India than the ALP. An enhanced majority for Modi also gave them confidence New Delhi might be bolder in reform, including economic liberalisation (Brewster 2019). With that in mind, Morrison embarked on a charm offensive, tweeting a selfie with Modi from the G20 meeting in Osaka, Japan, in June 2019 with a Hindi rendering of one of the Australian Prime Minister's catchphrases: kithana acche he Modi or 'how good is Modi?' (SBS Hindi 2019a). A short while later, in a major foreign policy speech delivered at the Lowy Institute in Sydney, Morrison lavished praise on India, a 'land of durable institutions and shared values', which he called a 'natural partner' for Australia (Morrison 2019).

This renewed bonhomie, a contrast from the Turnbull era, was reinforced by renewed diplomatic engagement on the Australian side and more work on defence and security cooperation. In early November 2019 it was leaked to the media that Barry O'Farrell, the former Liberal Party premier of New South Wales, would be Australia's next High Commissioner to India (Aston 2019). This was a highly symbolic move: Australian governments regularly send political grandees to serve as ambassadors in Washington, London, and Tokyo, but had never done so to New Delhi. O'Farrell's appointment upgraded the post, albeit informally, to the first rank of Australia's overseas missions, signalling the importance of the bilateral relationship. Then, at their virtual summit in June 2020, Modi and Morrison unveiled a new vision statement on maritime cooperation, signed a logistics support agreement to facilitate future humanitarian and disaster relief efforts and joint exercises, and upgraded the relationship to a 'Comprehensive Strategic Partnership'. Work advanced too in the areas of broader collaboration on defence technology and on cyber security initiatives (DFAT 2020). A long-anticipated invitation to the Royal

\footnotetext{
16 See, for example, Harinder Sidhu's speech to the Indian Council for Research on International Economic Relations (Sidhu 2016).
} 
Australia Navy to participate once more in MALABAR - the exercise from which it had been barred after Rudd's pull-out from the first iteration of the Quad back in early 2008-came later in October (Department of Defence 2020). And the same month saw a ministerial-level meeting of the Quad in Tokyo-the first in the region, following a gathering of the four foreign ministers on the sidelines of the United Nations General Assembly in September 2019. Together, these developments suggested ever greater strategic convergence between Australia and India, driven by shared concerns about China (Jaishankar 2020).

In the background, however, two problematic issues loomed. One was trade. New Delhi's promised Australia Economic Strategy failed to materialise in 2019 (SBS Hindi 2019b). A further pledge to release a document in January 2020 was not met; indeed, it was not published until December (Confederation of Indian Industry 2020). Moreover, although Modi and Morrison promised during the June 2020 online summit to restart negotiations for the CECA, New Delhi's commitment to what it called Atmanirbhar Bharat ('Self-Reliant India') in the budget announced a month earlier suggested that reaching agreement might be difficult. In essence, Atmanirbhar Bharat implies a doubling down on the existing strategy of attempting to boost manufacturing by attracting foreign capital and know-how, while protecting key sectors like agriculture with high tariff barriers, rather than the kind of liberalisation the Australian business community would like to see New Delhi pursue (Prakash 2010).

The second issue was what some in Australia-and elsewhere-perceived as the Modi government's growing illiberalism (Varshney 2019). Reports of curbs on press freedom, as well as physical assaults on journalists; allegations of ideologically motivated interference in universities; and accusations of complicity in attacks on Muslims, in particular, have been met with mounting concern, both within parts of the Indian diaspora and the wider Australian community (Thakur 2020). So too has New Delhi's approach to managing unrest in Kashmir (Kumar 2020). And while these doubts are not yet widespread in the Australian community or indeed in parliament, they do have the potential to complicate the push to strengthen the strategic partnership.

\section{Conclusion}

In the Modi era, as in the decade that preceded it, China's growing power and assertiveness have catalysed a strategic partnership between Australia and India. Shared concerns about Beijing's intentions and capabilities have overridden Canberra's disappointment about the Modi government's commitment to economic liberalisation and lifting bilateral trade and investment. They have also justified the setting aside of qualms about the state of India's democracy and the BJP's Hindu nationalist domestic agenda, which grew more overt after its second election win in May 2019. At the same time, similar anxieties in New Delhi have driven India's strategic elite to engage more deeply with a country that it has never considered anything close to being a peer. Australia has never really been, as one analyst rightly observes, 'in the first rank of India's international priorities' (Jha Bhaskar 2019). The view that is it 
relatively inconsequential - that it lacks 'capacity and critical mass', as one former High Commissioner to Canberra put it (Nanda 2020)—persists, especially among those that believe it is too dependent on China and too divided about managing the challenges it generates. To be sure, Australia's niche capabilities are increasingly appreciated by some in New Delhi, but the partnership remains unequal: one that has been built up with skill and one that has proved resilient so far, but one that continues to be driven forward more by Australia than India, despite the Modi government's energy and pledges of commitment.

\section{Compliance with ethical standards}

Conflict of interest On behalf of all authors, the corresponding author states that there is no conflict of interest.

\section{References}

Aston, J. 2019. Barry O'Farrell to be Australia's next ambassador to India, Australian Financial Review, 3 November, https://www.afr.com/rear-window/barry-o-farrell-to-be-australia-s-next-ambassador -to-india-20191103-p536yl.

Australian Associated Press. 2007. Uranium sales to India gets OK, Sydney Morning Herald, 17 August, https://www.smh.com.au/national/uranium-sales-to-india-gets-ok-20070817-gdqvov.html.

Australian Bureau of Statistics. 2018. Migration, Australia, 2017-18: Australia's Population by Country of Birth, https://www.abs.gov.au/ausstats/abs@.nsf/Latestproducts/3412.0Main\%20Features22017 -18 .

Australian Senate. 1990. Australia-India Relations: Trade and Security. Canberra: Australian Government Publishing Service.

Bachhawat, A. 2019. 'No longer in a cleft stick: India and Australia in the Indo-Pacific', The Strategist, 25 June, https://www.aspistrategist.org.au/no-longer-in-a-cleft-stick-india-and-australia-in-theindo-pacific/.

Basrur, R., and S. Narayanan Kutty. 2018. India and Japan: Assessing the Strategic Partnership. New York: Palgrave.

Bisley, N. 2017. Australia and India: some way to go yet, The Conversation, 12 April, https://theconvers ation.com/australia-and-india-some-way-to-go-yet-76085.

Bonnor, J. 2001. Australia-India Security Relations: Common Interests or Common Disinterests? Working Paper no. 67. Canberra: Australian Defence Studies Centre.

Borah, R. 2008. Australia-India Relations during the Howard Era. In India-Australia Relations: Convergences and Divergences, ed. D. Gopal. Shipra: Delhi.

Brewster, D. 2010. Australia and India: The Indian Ocean and the Limits of Strategic Convergence. Australian Journal of International Affairs 64(5): 549-565.

Brewster, D. 2015. The Australia-India Framework for Security Cooperation: Another step towards an Indo-Pacific security partnership. Security Challenges 11(1): 39-48.

Brewster, D. 2017. Constructing an Indo-Pacific Partnership: Modi's Engagement with Australia. In Modi and the World: (Re)Constructing Indian Foreign Policy, ed. S. Singh, 25-42. Singapore: World Scientific.

Brewster, D. 2019. NaMo and ScoMo: Business as usual. Australia India Institute, 24 May, https://www. aii.unimelb.edu.au/blog/indian-election-series/namo-and-scomo-business-as-usual/.

Broinowski, R. 2000. India, China and Australia: The Fractured Triangle. South Asia: Journal of South Asian Studies 23(1): 141-150.

Burns, N. 2014. Passage to India: What Washington Can Do to Revive Relations with New Delhi. Foreign Affairs 93: 132-143. 
Campbell, J. 2017. Prime Minister Malcolm Turnbull lands in India for four-day visit, news.com.au, 10 April, https://www.news.com.au/national/politics/prime-minister-malcolm-turnbull-lands-in-india -for-fourday-visit/news-story/a0fa940c61ca05c3e17bb8912cbcd438.

Chacko, P., and A. Davis. 2017. The Natural/Neglected relationship: Liberalism, Identity and India-Australia Relations. The Pacific Review 30(1): 26-50.

Chubb, D. 2017. Issues in Australian Foreign Policy July to December 2016. Australian Journal of Politics and History 63(2): 270-283.

Clarke, M. 2011. Australia, India and the Uranium Question. Australian Journal of Political Science 46(3): 489-502.

Confederation of Indian Industry. 2020. Australia Economic Strategy Report, https://aes2020.in.

Department of Defence. 2006. Submission no. 20: Inquiry into Australia's relationship with India as an emerging world power. Canberra: Joint Standing Committee on Foreign Affairs, Defence and Trade.

Department of Defence. 2009. Defending Australia in the Asia-Pacific Century: Force 2030, Canberra: Commonwealth of Australia, https://www.defence.gov.au/whitepaper/2009/docs/defence_white _paper_2009.pdf.

Department of Defence. 2013. Defence White Paper 2013: Defending Australia and its National Interests. Canberra: Commonwealth of Australia, https://www.defence.gov.au/whitepaper/2013/docs/ WP_2013_web.pdf.

Department of Defence. 2015. Joint Communiqué - India - Australia Defence Ministers' Meeting, 3 September, https://www.minister.defence.gov.au/minister/kevin-andrews/statements/minister-defencejoint-communique-india-australia-defence.

Department of Defence. 2020. Australia to participate in Exercise Malabar 2020, 19 October, https:// www.minister.defence.gov.au/minister/lreynolds/media-releases/australia-participate-exercisemalabar-2020.

Department of Prime Minister and Cabinet. 2012. Transcript of Press Conference - New Delhi, India, 17 October, https://pmtranscripts.pmc.gov.au/release/transcript-18854.

Derewlany, N. 2017. With the RCEP, Australia Has a Chance to Lead, The Diplomat, 30 August, https:// thediplomat.com/2017/08/with-the-rcep-australia-has-a-chance-to-lead/.

DFAT. 1994. India's Economy at the Midnight Hour: Australia's India Strategy. Canberra: Australian Government Publishing Service.

DFAT. 2001. India - Australia strategic dialogue, PA/12/2001, 30 August, https://india.embassy.gov.au/ ndli/PA_12_01.html.

DFAT. 2003. Australia And India Sign Counter-Terrorism MOU, Media Release, 28 August, FA107, https://foreignminister.gov.au/releases/2003/fa107_03.html.

DFAT. 2012. Australia in the Asian Century. Canberra: Commonwealth of Australia, https://apo.org.au/ sites/default/files/resource-files/2012-10/apo-nid31647.pdf.

DFAT. 2014a. Joint Statement by Prime Minister Abbott and Prime Minister Modi, 5 September, https ://www.dfat.gov.au/geo/india/Pages/joint-statement-by-prime-minister-abbott-and-prime-ministermodi-visit-to-india-september-2014.

DFAT. 2014b. Joint Statement by Prime Minister Abbott and Prime Minister Modi, Brisbane, 18 November, https://www.dfat.gov.au/geo/india/Pages/joint-statement-by-prime-minister-abbott-and-prime -minister-modi-brisbane-november-2014.

DFAT. 2017a. Joint Statement by Prime Minister Turnbull and Prime Minister Modi, 10 April, https:// www.dfat.gov.au/geo/india/Pages/joint-statement-by-prime-minister-turnbull-and-prime-ministermodi-visit-to-india-2017.

DFAT. 2017b. 2017 Foreign Policy White Paper: Opportunity Security Strength, https://www.dfat.gov.au/ sites/default/files/2017-foreign-policy-white-paper.pdf.

DFAT. 2020. Joint Statement on a Comprehensive Strategic Partnership between Republic of India and Australia, https://www.dfat.gov.au/geo/india/Pages/joint-statement-comprehensive-strategic-partn ership-between-republic-india-and-australia.

Envall, H.D.P., and I. Hall. 2016. Asian Strategic Partnerships: New Practices and Regional Security Governance. Asian Politics and Policy 8(1): 87-105.

Friedberg, A.L. 2014. The Sources of Chinese Conduct: Explaining Beijing's Assertiveness. The Washington Quarterly 37(4): 133-150.

Gopal, D., and D. Ahlawat. 2015. Australia-India Strategic Relations: From Estrangement to Engagement. India Quarterly 71(3): 206-220. 
Gordon, S. 1993. The Search for Substance: Australia-India Relations into the Nineties. Canberra: Australian National University.

Gordon, S. 1995. India's Rise to Power in the Twentieth Century and Beyond. Basingstoke: Macmillan.

Gordon, S., and S. Henningham. 1995. India Looks East: An Emerging Power and its Asia-Pacific Neighbours. Canberra: Strategic and Defence Studies Centre.

Gordon, S. 2014. India's Rise as an Asian Power: Nation, Neighbourhood, and Region. Washington, DC: Georgetown University Press.

Graham, E., Pan, C., Hall, I., Kersten, R., Zala, B., \& Percy, S. 2018. Debating the Quad. Centre of Gravity 19. Canberra: Strategic and Defence Studies Centre, Australian National University.

Grare, F. 2017. India Turns East: International Engagement and US-China Rivalry. London: Hurst.

Gurry, M. 1992. Leadership and bilateral relations: Menzies and Nehru, Australia and India, 19491964. Pacific Affairs 65(4): 510-526.

Gurry, M. 1996. India: Australia's Neglected Neighbour? 1947-1996. Brisbane: Centre for the Study of Australia-Asia Relations, Griffith University.

Gurry, M. 2012. India, the New Centre of Gravity: Australia-India relations under the Howard Government. South Asia: Journal of South Asian Studies 35(2): 282-305.

Gyngell, A. 2017. Fear of Abandonment: Australia and the World since 1942. Carlton, VIC: La Trobe University Press.

Hall, I. 2014. Australia's Fitful Engagements of India. In The Engagement of India: Strategies and Responses, ed. I. Hall, 129-146. Washington, DC: Georgetown University Press.

Hall, I. 2016. India in Australia's 2016 Defence White Paper. Security Challenges 12(1): 181-186.

Hall, I. 2019a. The Struggle to Maintain Momentum in the Australia-India Partnership, The Asan Forum, 11 February, http://www.theasanforum.org/the-struggle-to-maintain-momentum-in-theaustralia-india-partnership/.

Hall, I. 2019b. Modi and the Reinvention of Indian Foreign Policy. Bristol: Bristol University Press.

Hall, I. 2020a. India and a Regional Rules-Based Order: Equity and Inclusion. Security Challenges $16(1), 27-31$.

Hall, I. 2020b. India and the Belt and Road Initiative: From Critic to Competitor. In The Belt and Road Initiative and the Future of Regional Order in the Indo-Pacific, ed. M. Clarke, M. Sussex, and N. Bisley. Lanham: Lexington.

Hindustan Times. 2013. Now, Australia invites Modi for visit, 17 August, https://www.hindustant imes.com/india/now-australia-invites-modi-for-visit/story-sjgiXgK6mbFlsZJSr5OdHI.html.

Jaishankar, D. 2020. The Australia-India Strategic Partnership: Accelerating Security Cooperation in the Indo-Pacific, 17 September, https://www.lowyinstitute.org/publications/australia-india-strat egic-partnership-security-cooperation-indo-pacific.

Jeffrey, R. 2018. Australia and India: Is it Different this Time? InsideStory, 14 August, https://insid estory.org.au/australia-and-india-is-it-different-this-time/.

Jha Bhaskar, N. 2019. Australia-India ties: closing the gap between intent and action, The Interpreter, 22 March, https://www.lowyinstitute.org/the-interpreter/australia-india-ties-closing-gap-betwe en-intent-and-action.

Kaul, M.M. 2000. Australia-India Relations: Post-Pokhran II Phase. International Studies 37(4): $365-375$.

Kaura, V. 2020. India's Relations with China from the Doklam Crisis to the Galwan Tragedy. India Quarterly 76(4): 501-518.

Kehoe, J. 2016. Donald Trump's TPP retreat 'damaging', says Joe Hockey. Australian Financial Review, 14 December. https://www.afr.com/world/donald-trumps-tpp-retreat-damaging-saysjoe-hockey-20161214-gtakox.

Kelly, P. 2006. Howard's Decade: An Australian Foreign Policy Reappraisal, Lowy Institute Paper 15. Sydney: Lowy Institute for International Policy.

Kumar, V. 2020. Activists appeal Australia to speak up on 'human rights violations' in India, SBS Hindi, 23 October, https://www.sbs.com.au/language/english/audio/activists-appeal-australiato-speak-up-on-human-rights-violations-in-india.

Ladwig III, W. C., and Mukherjee, A. 2017. Trump and Modi: Seeking a Global Partnership? RSIS Commentaries 125, https://dr.ntu.edu.sg/bitstream/10220/42759/1/CO17125.pdf.

Lang, D. 2015. The not-quite-quadrilateral: Australia, Japan and India, The Strategist, 9 July, https:// www.aspistrategist.org.au/the-not-quite-quadrilateral-australia-japan-and-india/.

Lee, J. 2009. The Importance of India: Restoring Sight to Australia's Strategic Blind Spot, Sydney: Centre for Independent Studies, November, https://core.ac.uk/download/pdf/30675142.pdf. 
Madan, T. 2017. The Rise, Fall and Rebirth of the Quad, War on the Rocks, 16 November, https:// warontherocks.com/2017/11/rise-fall-rebirth-quad/.

Mayer, P., and P. Jain. 2010. Beyond Cricket: Australia-India Evolving Relations. Australian Journal of Political Science 45(1): 133-148.

MEA. 2014. Prime Minister's Address to the Joint Session of the Australian Parliament, 18 November, https://www.mea.gov.in/Speeches-Statements.htm?dtl/24269/Prime_Ministers_Address_to_the_ Joint_Session_of_the_Australian_Parliament_18_November_2014.201.

MEA. 2015. India-US Delhi Declaration of Friendship, 25 January 2015, https://www.mea.gov.in/bilat eral-documents.htm?dtl/24727/indiaus+delhi+declaration+of+friendship.

MEA. 2017. Official Spokesperson's response to a query on participation of India in OBOR/BRI Forum, 17 May, https://www.mea.gov.in/media-briefings.htm?dt1/28463/Official_Spokespersons_respo nse_to_a_query_on_participation_of_India_in_OBORBRI_Forum.

MEA. 2018. Prime Minister's Keynote Address at Shangri La Dialogue, 1 June, https://mea.gov.in/Speec hes-Statements.htm?dtl/29943/Prime+Ministers+Keynote+Address+at+Shangri+La+Dialo gue+June+01+2018.

Medcalf, R. 2008. Australia-India Relations: Hesitating on the Brink of Partnership, Asia Pacific Bulletin 13 (East-West Center), 3 April, https://www.eastwestcenter.org/system/tdf/private/apb01 3.pdf?file $=1 \&$ type $=$ node $\&$ id $=32261$.

Medcalf, R. 2011. Grand Stakes: Australia's Future between China and India. In Strategic Asia 20112012: Asia Responds to its Rising Powers, China and India, ed. A.J. Tellis, T. Tanner, and J. Keough, 195-226. Seattle and Washington, DC: National Bureau of Asian Research.

Medcalf, R. 2019. Australia and China: Understanding the Reality Check. Australian Journal of International Affairs 73(2): 109-118.

Medcalf, R. and Rajendram, D. 2014. India's Narendra Modi is good news for Australia, Sydney Morning Herald, 19 May, https://www.smh.com.au/opinion/indias-narendra-modi-is-good-news-for-austr alia-20140519-zrhdd.html.

Mehra, P. 2019. The Lost Decade, 2008-2018: How India's Growth Story Devolved into Growth without a Story. New Delhi: Ebury.

Minister for Foreign Affairs. 1998. Australian Response to India Nuclear Tests, Media Release, 14 May, FA59, https://foreignminister.gov.au/releases/1998/fa059_98.html.

Mistry, D. 2014. The US-India Nuclear Agreement: Diplomacy and Domestic Politics. New Delhi: Cambridge University Press.

Modi, N. 2014. World Leaders Congratulate Modi on Record Win, 16 May, https://www.narendramo di.in/world-leaders-greet-narendra-modi-on-record-win-6215.

Morrison, S. 2019. The 2019 Lowy Lecture, 4 October, https://www.lowyinstitute.org/publications/2019lowy-lecture-prime-minister-scott-morrison.

Nanda, B. 2020 Prospects for closer strategic ties between India and Australia, The Interpreter, 2 June, https://www.lowyinstitute.org/the-interpreter/prospects-closer-strategic-ties-between-india-andaustralia.

Palit, A. 2017. Modi's Foreign Economic Policy. In Modi and the World: (Re) Constructing India's Foreign Policy, ed. S. Singh, 139-162. Singapore: World Scientific.

Panda, R., and P. Baruah. 2010. India-Australia Strategic Partnership: A Case for a Holistic Approach. India Quarterly 66(2): 203-221.

Prakash, A. 2020. Modi's repackaging of old industrial policy won't salvage India. East Asia Forum, 2 June, https://www.eastasiaforum.org/2020/06/02/modis-repackaging-of-old-industrial-polic y-wont-salvage-india/.

PTI. 2019. India pulls out of RCEP: Industry, traders and farmers welcome Narendra Modi govt's decision, FirstPost, 5 November, https://www.firstpost.com/india/india-pulls-out-of-rcep-industry-trade rs-and-farmers-welcome-narendra-modi-govts-decision-7603461.html.

Rajagopalan, R. 2017. US-India Relations under President Trump: Promise and Peril. Asia Policy 24(2017): 39-45.

Roy, E. 2011. Australian Uranium and India: Ideology versus Pragmatism. South Asia: Journal of South Asian Studies 34(1): 113-140.

SBS Hindi. 2019a. Kithana acha he Modi, Scott Morrison tweets, 1 July, https://www.sbs.com.au/langu age/english/kithana-acha-he-modi-scott-morrison-tweets.

SBS Hindi. 2019b. India to release Australia Economic Strategy Report, 14 December, https://www.sbs. com.au/language/english/india-to-release-australia-economic-strategy-report. 
Shekhar, V. 2010. India and Australia in the Twenty-First Century: Emerging Parameters of Strategic Engagement. India Quarterly 66(4): 397-412.

Sidhu, H. 2016. Pathways to Trade Liberalisation, 1 June, https://india.highcommission.gov.au/ndli/speec hhc0601.html.

Singh, A. .2019. India Bides its Time in Indian Ocean. East Asia Forum, 8 February, http://www.easta siaforum.org/?p=168487.

Soz, S.A. 2019. The Great Disappointment: How Narendra Modi Squandered a Unique Opportunity to Transform the Indian Economy. New Delhi: Penguin.

Suryanarayana, P. S. 2000. Differences must not affect new dialogue: John Howard, The Hindu, 26 June, https://www.thehindu.com/thehindu/2000/06/27/stories/01270009.htm.

Tellis, A.J. 2005. India as a New Global Power: An Action Agenda for the United States. New Delhi: India Research Press.

Thakur, R. 2013. Follow the Yellowcake Road: Balancing Australia's National Interests against International Anti-Nuclear Interests. International Affairs 89(4): 943-961.

Thakur, R. 2020. India's friends can't ignore its slide from democracy. The Strategist, 13 March, https:// www.aspistrategist.org.au/indias-friends-cant-ignore-its-slide-from-democracy/.

Tow, W.T. 2017. President Trump and the Implications for the Australia-US Alliance and Australia's Role in Southeast Asia. Contemporary Southeast Asia: A Journal of International and Strategic Affairs 39(1): 50-57.

Tow, W.T. 2019. Minilateral Security's Relevance to US Strategy in the Indo-Pacific: Challenges and Prospects. The Pacific Review 32(2): 232-244.

Turnbull, M. 2016. The 2016 Lowy Lecture, 23 March, https://www.lowyinstitute.org/publications/2016lowy-lecture-prime-minister-australia-malcolm-turnbull.

Turnbull, M. 2020. A Bigger Picture. Richmond, VIC: Hardie Grant.

Varghese, P. 2018. India Economic Strategy to 2035. Canberra: Department of Foreign Affairs and Trade, https://www.dfat.gov.au/geo/india/ies/index.html.

Varshney, A. 2019. Modi Consolidates Power: Electoral Vibrancy, Mounting Liberal Deficits. Journal of Democracy 30(4): 63-77.

Vicziany, M. 1993. Australia-India, the Economic Links: Past, Present, and Future. Perth: Indian Ocean Centre for Peace Studies.

Wade, M. 2014. Indian Prime Minister Narendra Modi draws thousands to Sydney Olympic Park, Sydney Morning Herald, 17 November, https://www.smh.com.au/national/nsw/indian-prime-ministernarendra-modi-draws-thousands-to-sydney-olympic-park-20141117-11oe5f.html.

Weigold, A. 2011. Engagement versus Neglect: Australia in the Indian Ocean, 1960-2000. Journal of the Indian Ocean Region 7 (1): 32-51.

Wilson, J. 2019. India's RCEP exit a setback, but not a disaster, The Interpreter, 6 November, https:// www.lowyinstitute.org/the-interpreter/india-s-rcep-exit-setback-not-disaster.

Publisher's Note Springer Nature remains neutral with regard to jurisdictional claims in published maps and institutional affiliations. 